\title{
COMPARATIVE STUDY OF MINERAL CONTENT OF SIDAT FISH MEAT (ANGUILLA MARMORATA QUOY GAIMARD) ON YELLOW EEL PHASE FROM PALU RIVER AND LAKE POSO
}

\author{
1* Jamaluddin, ${ }^{1}$ Dewi Safitri, ${ }^{1}$ Agustinus Widodo \\ ${ }^{1}$ Department of Pharmacy, Faculty of Mathematics and Natural Sciences, Tadulako University, Palu, Indonesia \\ * Corresponding author: jamal_farmasi02@yahoo.co.id \\ Co-author 1, email: widodoagustinus@yahoo.com
}

\begin{abstract}
Eel fish (Anguilla marmorata Quoy Gaimard) is one of the strategic commodities to be developed because it has high nutritional value such as protein, fatty acid, vitamins and minerals. Minerals are one of the nutrients the body needs for the body's physiological processes. This study aims to determine the amount and mineral content of eel meat Anguilla marmorata Quoy Gaimard) originating from the river Palu and lake Poso. Sampling was done by Purposive sampling method based on type, weight 35-40 gram, size 300-450 mm and location of taking. Mineral testing on eel meat using laboratory experimental with Inductively Coupled Plasma Mass Spectrometry (ICP-MS). The results showed that the mineral content contained in yellow eel fish from Palu river contains potassium 1,519 mg/kg, magnesium 203 $\mathrm{mg} / \mathrm{kg}$, zinc $11,2 \mathrm{mg} / \mathrm{kg}$, and mercury $0,129 \mathrm{mg} / \mathrm{kg}$; and from the Poso lake contains potassium 1,360 mg/kg, magnesium $179 \mathrm{mg} / \mathrm{kg}$, and strontium $1.32 \mathrm{mg} / \mathrm{kg}$. Based on this study can be concluded that there is influence the location against the amount of mineral content.
\end{abstract}

Keywords: Anguilla marmorata, mineral

\section{INTRODUCTION}

Fish is one of the most important sources of nutrients for human survival. Indonesia is the second largest Megabiodiversity country after Brazil, which has 1300 species of freshwater fish with a density of 0.72 species $/ 1000 \mathrm{~km} 2$ [4]. One of the areas of Indonesia that has many freshwater fish is Sulawesi, the high endemicity level found in Central Sulawesi (Lake Poso) and South Sulawesi (Matano Lake and Towuti Lake) [6].

In Central Sulawesi in particular, the famous waters of Lake Poso have the highest freshwater fish potential. Some species of freshwater fish in Lake Poso include cork (Channa striata), betok (Anabas testudineus), nilem (Osteochilus hassetii), sogili (Anguilla sp.), indigo (Oreochromis noliticus), anasa (Nomorhampus celebensis) temple batu (Tamanka sarasinorum) and Rono (Oryzias nigrimas) [13]. The Poso region has one of the highest freshwater fish potentials of eel (sogili) because it is supported by a deep enough Tomini Bay 
and the presence of extensive inland waters of the Poso lake. There are 5 (five) types of fish eel in lake Poso, they are Anguilla marmorata (Q.) Gaimard, Anguilla celebensis, Anguilla interioris, Anguilla bicolorpacific, and Anguilla bornroensis [7].

In addition to Poso Lake, there is also Palu River, which has potential of eel fish. The current research has tended to focus on the River and Lake in Poso, so that the data available is very less in other Rivers or Lakes located in Central Sulawesi, especially Palu River. According Ndobe S. [9] there are 3 (three) eels located in Teluk Palu River, they are Anguilla marmorata (Q.) Gaimard, Anguilla celebensis, and Anguilla bicolorpacific.

Besides protein, carbohydrates, and fat, fish has minerals that is also very necessary for the body to maintain balance of acid and base of the body, and take a part in the growth and maintenance of bones, teeth and other tissues of the body. In the study, the amount and mineral content of eel meat (Anguilla marmorata Quoy Gaimard) from Palu and Poso lakes was determined using Inductively Coupled Plasma Mass Spectrometry (ICP-MS). Selection of different habitats to obtain information related to their mineral content.

\section{MATERIAL AND METHOD}

\section{Materials}

Yellow eel (Anguilla marmorata Quoy Gaimard) weight 35-40 gram and size 300-450 $\mathrm{mm}, \mathrm{HNO}_{3}$, Beryllium, Cobalt, Indium, Barium, Lead, Thorium, Uranium, Magnesium, Potassium, Zinc, Strontium, Mercury, and aquadest.

\section{Instrumentation}

Inductively Couple Plasma Mass Spectrometry (ICP-MS) Nexion 300x Perkin Elmer, Microwave digestion (Mars Xpress Microwave Digestion).

\section{Procedure}

\section{Sample preparation}

The samples used in this study were eel (Anguilla marmorata Quoy Gaimard) taken from Poso lake and Palu river, Fish was caught using a net in the river and lake area, then put into polystyrene container and given ice, then the sample was separated from bone and head (fillets) and washed with running water, then mashed with a blender until homogeneous and place in a clean and closed container, stored in room temperature $\left(20-25^{\circ} \mathrm{C}\right)$ in a stainless steel container until the time is analyzed [8]. 
The destruction method used is microwave destruction, each sample weighed as much as 0.3 grams and then inserted into the vessel. Added $6 \mathrm{ml}$ of concentrated $\mathrm{HNO}_{3}$. Conducted pre-digest for 10-15 minutes. After that the vessel is inserted into the protective shield, then closed with a lid and tightened. The vessel is inserted into the microwave digestion, then connected to the temperature sensor, performed in two stages. First stage set temperature $150^{\circ} \mathrm{C}$ and second stage with a temperature of $200^{\circ} \mathrm{C}$. After the destruction process has finished the vessel is removed and cooled to room temperature, then the vessel is opened. The resultant destruction solution from the vessel was collected in a measuring flask diluted with aquadest of $8 \mathrm{ml}$.

\section{Qualitative analysis}

The qualitative test used a screening element method on an ICP-MS device with an external standard solution called "Smartune" containing Be $1 \mu \mathrm{g} / \mathrm{L}$, Co $1 \mu \mathrm{g} / \mathrm{L}$, In $1 \mu \mathrm{g} / \mathrm{L}$, Ba $10 \mu \mathrm{g} / \mathrm{L}, \mathrm{Pb} 1 \mu \mathrm{g} / \mathrm{L}$, Th $1 \mu \mathrm{g} / \mathrm{L}$ and $\mathrm{U} 1 \mu \mathrm{g} / \mathrm{L}$. Screening elements are tested based on the mass of defined minerals, ie with a vulnerable mass number between 6 to 240 .

\section{Quantitative analysis}

Quantitative test, external standard calibration with concentration of each element tested is $\mathrm{Mg} 100 \mu \mathrm{g} / \mathrm{L}, \mathrm{K} 100 \mu \mathrm{g} / \mathrm{L}, \mathrm{Zn} 50 \mu \mathrm{g} / \mathrm{L}, \operatorname{Sr} 50 \mu \mathrm{g} / \mathrm{L}$ and $\mathrm{Hg} 50 \mu \mathrm{g} / \mathrm{L}$. Of the samples already in the digestion of $6 \mathrm{ml}$ were included in the sample tube in ICP MS for analysis. Testing uses a quantitative method whereby it will be seen and each mineral is measured.

\section{RESULTS AND DISCUSSION}

The result of analysis of the mineral content of eel meat (Anguilla marmorata Quoy Gaimard) taken from Palu river and Poso lake is very different, Palu river eel meat has more mineral content than eel meat from the Poso lake (Table 1). The mineral is needed by the body, important in maintenance function body good on level cells, tissues, organs, as well function body with whole [1]. Minerals needed in a number of very small that is starting from $1 \mathrm{mg}$ to $2500 \mathrm{mg}$ daily. It depends on type minerals [2]. Mineral deficiency in the body could cause various interference function body, such as anemia, diarrhea, blindness and deaf on children, mumps and others. Mineral fish is needed for synthesis substance food, process muscle formation, metabolism of fish, protein synthesis and process growth [12]. The fulfillment mineral requirement on human could obtained from food such as animal minerals that is fish sea as well freshwater fish. In Central Sulawesi exactly in Lake Poso has potency 
freshwater fish the highest that is fish eel (Anguilla marmorata Quoy Gaimard), besides Lake Poso there is too river Palu who have potency fish eel.

Location taking sample that is Palu river and Poso Lake which aims for look difference mineral content on fish eel (Anguilla marmorata Quoy Gaimard) that depends on internal factors and external. Where Internal factors such as type or species of fish, types sex, age, and phase production, whereas factor external form factors are there on environment life fish such as habitat, availability feed, and quality waters the place life fish [5].

Minerals are divided be two essential minerals and non essential. Essential minerals divided into the two groups, namely macro minerals comprising from the minerals of sodium, calcium, magnesium, potassium, chloride and strontium while the micro mineral composed of iron, iodine, manganese, copper, zinc, cobalt, flour, and selenium. And for non essential minerals composed of mercury, lead, arsenic, aluminum, cadmium.

Before sample analyzed, samples must in destruction more first, for destroying compound organic in a sample to obtain a sample with solution clear for analyzed. On research this use Destruction microwave digestion, which is developed from destruction wet where with microwave digestion not much material is lost with very high temperatures. This is one of the factors why more wet ways are used. In addition, wet destruction is usually done to improve the dry way that takes a long time. Next sample added compound acid strong concentrated $\mathrm{HNO}_{3}$ to help oxidize ingredients organic. After sample done at destruction, done testing qualitative use ICP-MS tool that has a sensitivity and accuracy is very good with method screening element to look how many samples were detected [14]. Results detection sample show presence of mineral potassium, magnesium, zinc, strontium and mercury. After that, sample was tested quantitative for calculating levels, from each sample of which has detected.

Analysis results show, Anguilla marmorata yellow eel phase from Palu river and Poso lake have each vary mineral content. Analyze mineral content of eel from Palu river getting results: potassium, magnesium, zinc, and non-essential mineral (mercury). And from Poso lake, obtained results include: potassium, magnesium and strontium.

Potassium mineral content is the highest in this study compared to other minerals (Table 1). Potassium in the cells acts as a catalyst in many biological reactions, especially in energy metabolism and glycogen and protein synthesis, potassium plays a role in cell growth [1]. According to the Minister of Health of the Republic of Indonesia Regulation No. 75 of 2013 
[15], about the number of nutritional adequacy rate recommended for the Indonesian nation per day for potassium mineral that is $4500 \mathrm{mg}-4700 \mathrm{mg}$.

Magnesium is an activator of peptidase enzyme and others enzyme that function to break down and move phosphate groups. Magnesium is needed for the body's metabolism of energy, carbohydrates, fats and proteins [12]. The nutritional adequacy rate recommended for the Indonesian nation per day for magnesium minerals of $150 \mathrm{mg}$ - $350 \mathrm{mg}$ [15].

Zinc is a micro mineral and only found in Palu river eel (Table 1). Zinc has an important role in protein synthesis and cell division. Zinc plays a role in the formation of insulin and its activity to heal wounds [11]. Zinc deficiency in humans will lead to short growing characteristics and delay in sexual maturation. Good food sources of zinc are fishery products [1]. The nutritional adequacy rate recommended for the Indonesian nation per day for zinc minerals of $13 \mathrm{mg}$ - $18 \mathrm{mg}$ [15].

Strontium in eel is only found in the Poso lake (Table 1). Strontium is very similar to calcium, strontium can be said to replace calcium intake. Because strontium works for bone strengthening in growing children, maximum strontium consumption $350 \mathrm{mg} / \mathrm{kg}$ per day [3].

Fish generally have the ability to avoid themselves from the effects of water pollution, but not so on fish living in restricted habitats (such as rivers, lakes and gulfs) difficult to escape from the pollution. The results of the research showed that the eels from Palu river were detected containing mercury compounds (Table 1) because of the gold mining activity around the area passed by Palu river. Mercury is one of the dangerous heavy metals, mercury poisoning can cause nervous system disorders, DNA and chromosomal damage, allergic reactions, and reproductive system damage The maximum limit of mercury concentration in fish and preparations is set in the Indonesian National Standard SNI 2009 is $0.5 \mathrm{mg} / \mathrm{kg}$, the detected mercury does not exceed the maximum limit of $0.129 \mathrm{mg} / \mathrm{kg}$ [16].

Difference mineral content in the composition of fish could caused by some factor the rate of metabolism, age, habitat, type sex, food and time span. According to Santoso [12], Presence of minerals in organism waters could affected by power absorption metal, which consists from some factor that is temperature an environmental, size organisms, species, $\mathrm{pH}$, and condition to lapse from the organism. 


\section{CONCLUSION}

The results of analysis of mineral composition of eel meat (Anguilla marmorata Quoy Gaimard) yellow eel phase from Palu River and Poso lake, there is a significant difference of mineral content of Potassium and Magnesium, where the mineral content of Palu fish from Palu river is higher than the origin of Poso lake.

\section{ACKNOWLEDGEMENTS}

The author would like to thank the institutions of the Lembaga Ilmu Pengetahuan Indonesia (LIPI) and PT. Angler BioChemlab who has helped to complete this research.

\section{REFERENCES}

[1] Almatsier, S., 2003. Prinsip Dasar Ilmu Gizi. Jakarta: PT Gramedia Pustaka Utama.

[2] Campbell, N.A. Reece, J.B., and Mitchell, L. W., 2004. Biologi, Volume III. Jakarta: Erlangga.

[3] Dorsey. F. A., 2004. Toxicological Profile For Strontium. Georgia. U.S. Department Of Health And Human Services. Public Health Service Agency For Toxic Substances And Disease Registry.

[4] FOA-Fisheri and Aquaculture Departments, 2010. The state of the world fisheries and aquaculture 2010. Food and Agriculture Organization of the United Nations. Rome.197p

[5] Hafiludin, 2015. Analisis Kandungan Gizi Ikan Bandeng Yang Berasal Dari Habitat Yang Berbeda. Marine Journal, Volume 8 No. 1

[6] Husnah. Thahjo. H.W.D. Nastiti, A. Oktaviani, A. Nasution, H.S. Sulistiono, 2008. Status Keanekaragaman Hayati Sumber Daya Perikanan Perairan Umum Sulawesi Tengah. Palembang: Fisheries Research Agency of Public Waters.

[7] McKinnon, L.J., 2006. A review of eel biology: Knowledge Victoria and Audentes Investments Pty Ltd.

[8] Mulyati, 2016. Analisis Komposisi Mineral pada Ikan Rono Lindu (Xenopocilus sarasinorum) dan Rono Poso (Xenopocilus oophorus) Endemik Sulawesi Tengah. Palu: Jurusan Farmasi. FMIPA Universitas Tadulako.

[9] Ndobe S., 2010. Struktur Ukuran Glass Eel Ikan Sidat (Anguilla marmorata) di Muara Sungai Palu. Kota Palu. Sulawesi Tengah: Media Litbang Sulteng. 3(2): 144-150.

[10] Ramlah, Soekendarsih. E., Hasyim. Z., and Hasan, S.M., 2016. Perbandingan Kandungan Gizi Ikan Nila Oreochromis niloticus Asal Danau Mawang Kabupaten Gowa dan Danau Universitas Hasanuddin Kota Makassar. Makassar: Jurnal Biologi Makassar (BIOMA). Vol.1 No.1

[11] Rohman, A. and Sumantri, 2007. Analisis Makanan. Yogyakarta: Gadjah Mada University Press

[12] Santoso, W., 2009. Komposisi Mineral Makro dan Mikro Daging Ikan Gurami (Osphrone gourany) Pada Berbagai Waktu Pemeliharaan. Bogor: Prodi Teknologi Hasil Perikanan IPB 
[13] Sawetri, S. and Atminarso, D., 2013. Status Trofik dan Estinasi Potensi Produksi Ikan Di Perairan Danau Poso Sulawesi Tengah. Balai Penelitian Perikanan Umum. Palembang

[14] Yusuf, S., 2014. Aplikasi Teknikan Di Rektor RSG-GAS Pada Penentuan Unsur Esensial dan Toksik Di Dalam Ikan dan Pakan Ikan. Batam Pusat Sains dan Teknologi Bahan Maju

[15] Indonesia, M. K. R., 2013. Peraturan Menteri Kesehatan Republik Indonesia Nomor 75 Tahun 2013 tentang angka kecukupan gizi yang dianjurkan bagi bangsa Indonesia. Jakarta: Kemenkes RI.

[16] Indonesia, S. N., 2009. Batas maksimum cemaran logam berat dalam pangan. Badan Standar Nasional, Jakarta.

Table 1. Minerals content Anguilla marmorata Quoy Gaimard

\begin{tabular}{ccc}
\hline \multirow{2}{*}{ Minerals } & \multicolumn{2}{c}{ Level (mg/kg) } \\
\cline { 2 - 3 } & Eel fish in Palu River & Eel Fish in Poso Lake \\
\hline Potassium & 1519 & 1360 \\
Magnesium & 203 & 179 \\
Zinc & 11,2 & - \\
Strontium & - & 1,32 \\
Mercury & 0,129 & - \\
\hline
\end{tabular}

